and mineralogy with a first-rate introduction to the use of the spacegroup diagrams in the International Tables.

It is easy to commend the author for pursuing his theme to the threshold of crystal structures and no further. He has achieved thereby a shorter and a better book. One would have liked, however, to see the obvious relation between Haüy's " molecule integrante" and the unit cell of the X-ray crystallographer explicitly stated. The sooner the student learns that the size of the unit of pattern of the crystal fabric can be measured the better. Why deny him the simple and logical derivation of the indices of crystal faces direct from the unit cell dimensions? Let him learn later that his less fortunate predecessor had to employ a more cumbersome derivation involving the choice of a parametral plane and axial ratios. One also questions the wisdom of introducing students to the limited truth of the DonnayHarker principle. No one is likely to embark on the determination of a space-group with an optical goniometer, when the X-ray method is so well established and certain. That instrument is much more likely to be employed, as it was formerly, for the determination of class symmetry and perhaps also applied to a more energetic attack on the problems of crystal growth and the study of the large-scale imperfections of real crystals.

F. A. B.

\title{
CORRESPONDENCE
}

\section{GALA-TARANNON BEDS IN THE PENTLAND HILES, NEAR EDINBURGH}

SIR,-Since my paper on the Gala-Tarannon Beds went to the press, a new graptolite assemblage has been collected from the base of a contorted sandy siltstone at Gypsy Point, south of Kirkcudbright. Dr. G. L. Elles has kindly identified the following forms : Cyrtograptus carruthersi Lapworth, C. lundgreni Tullb., Monograptus dubius Suess, $M$. flemingi Salt., M. flemingi var. compactus (Elles). This is the youngest graptolite fauna so far recorded in the Southern Uplands. The beds containing it appear to be younger than beds with erosion features, dragmarks and ripplemarks further north.

A. LAMONT.

Grant Institute of Geology, EDINBURGH.

August, 1947. 